\title{
Plant Growth, Fruit Yield and Mineral Content of Bottle Gourd (Lagenaria siceraria $M$ ) as Affected by Plant Density and Nitrogen Fertilizer
}

\author{
Samir K. El-Seifi; Mahmoud A. Hassan; Mohammed W.M. Elwan" and Salma A.M. Melouk \\ Department of Horticulture, Faculty of Agriculture, Suez Canal University, Ismailia, Egypt.
}

Received: $15 / 3 / 2015$

\begin{abstract}
This experiment was carried out during two successive summer seasons of 2012 and 2013 on bottle gourd landrace El-Arishy (Lagenaria siceraria $\mathrm{M}$ ) at the Experimental Research Farm of the Faculty of Agriculture, Suez Canal University, Ismailia, Egypt to study the effect of plant density and nitrogen fertilizer on plant growth, yield and its components as well as mineral content. The obtained results showed that the low plant population (1750 plant per fad.) gave the highest shoot fresh weight, shoot dry weight, average fruit weight, average fruit length and nitrogen content in shoots and fruits. However, the significant highest fruit yield and fruit number per faddan were associated with the high plant population (3500 plant per faddan). All previous mentioned parameters in addition to shoot and fruit phosphorus contents significantly improved by application of high nitrogen rate (20g/plant). Shoot and fruit potassium and phosphorus contents were not affected significantly by plant spacing. Fruit potassium content did not affect significantly by nitrogen fertilizer. All the above mentioned parameters were significantly higher with the interaction between low plant population (1750 plant per fad.) was combined with high nitrogen rate (20g/plant), except fruit yield (ton/fad.) and fruit number which increased by the combination of high plant population with high nitrogen rate. Potassium content did not affect by the interaction between plant spacing and nitrogen fertilizer.
\end{abstract}

\section{INTRODUCTION}

Bottle gourd (Lagenaria siceraria $\mathrm{M}$ ) is a diploid $(2 \mathrm{n}=2 \mathrm{x}=22)$ belonging to the genus Lagenaria of the Cucurbitaceae family (Beevy and Kuriachan, 1996). The bottle gourd can be easily distinguished from other pumpkin varieties by its white flowers and characteristic of fruit, seed and leaf shapes (Cutler and Whitaker, 1967). Worldwide, bottle gourd is grown for its young fruit which used as a vegetable. The fresh fruit, which usually has a light green smooth skin and a white flesh, is frequently used in many regions of Asia and Africa as either a stir-fry or soup vegetable ingredient (Morimoto and Mvere, 2004). Furthermore, in India different plant parts, especially the fruit juice can be used as medicine to cure stomach elements (Haque et al., 2009). Another recent utilization of bottle gourd is as rootstocks for watermelon against soil-born diseases and low soil temperature (Yetisir and Sari, 2003).

Bottle gourd was one of the first crops to be domesticated. Based on archaeological evidence, bottle gourd is presumed to have been domesticated in Africa (Decker-Walters et al., 2004; Whitaker, 1971) and might have dispersed to the new world by ocean currents or by human migration in pre-historic times (Erickson et al., 2005; Morimoto et al., 2005). Africa is believed to be the center of genetic diversity for bottle gourd, although wild progenitors of bottle gourd have not been identified there (Whitaker, 1971).

The relationship between crop yield and planting density (number of plant unit area) is of considerable agronomic interest (Holliday, 1960; Thorenley, 1983). It is clear that the density dependent effects on the yield are due to the competition between adjacent plants for the necessary natural resources. There is a basic assumption that a plant located at a given site is constrained to draw nutrients only from its immediate vicinity and this zone may be larger than the size of the actual plant both on the surface and into the ground (Pant et al, 1979). Since competition between plants greatly affect yield (Thorenley, 1983; Willey and Heath,
1969) it is therefore possible to adjust size of the harvested crop to meet the requirements of the market by manipulating density (Cushman et al., 2004). Effect of plant density on the yield and its component in cucurbita crops (Ban et al., 2011; Abd el Hamed and Elwan, 2011; Babayee et al., 2012; Latifi et al., 2012; Baloch et al., 2013) were studied.

Mineral fertilizers application is essential for plant growth, development and productivity of plants. However, the excessive amounts of nitrogen fertilizer would lead to un-favorite effect on the growth and yield of plants and will lead to increase the losses of nitrogen fertilizer. So, the adequate amounts of nitrogen fertilization led to improve growth, yield and quality. There are some supporting studies that $\mathrm{N}$ fertilization affects plant growth and yield of cucurbita plants (Heidari and Mohammad, 2012; Ndor and Dauda, 2013; He-xi et al., 2011; Ng'etich et al., 2013).

A few literatures were found on the interaction effect between the plant density and nitrogen fertilizer on the yield and its components of cucurbitaceace (Rieners and Riggs, 1997; Goreta et al., 2005; Sabo et $a l ., 2013)$ and there is only one publication was found on bottle gourd (Jan et al., 2000).

This study was done with the objective of testing the hypothesis whether the interaction between nitrogen fertilizer and plant density will affect plant growth, yield and mineral contents of bottle gourd plants (Lagenaria siceraria $\mathrm{M}$ ) landrace El-Arishy collected from Sinai region under the condition of Ismailia Governorate or not.

\section{MATERIALS AND METHODS}

\section{Plant materials and treatments}

This investigation was carried out during two successive summer seasons of 2012 and 2013 on bottle gourd plants (Lagenaria siceraria M) landrace ElArishy grown on sandy soil at the Experimental Research Farm of the Faculty of Agriculture, Suez Canal University, Ismailia, Egypt to study the effect of 
different plant density and nitrogen fertilization levels on vegetative growth, yield and plant mineral content.

The soil of the experimental site was sandy in texture $(85.21 \%$ sand, $11.5 \%$ silt and $3.29 \%$ clay) with EC $1.5 \mathrm{dsm}^{-1}$ and $\mathrm{pH} 7.31$ (average the two seasons). The soil was prepared by adding $20 \mathrm{~m}^{3}$ per faddan of farmyard manure. Afterward, the ridges were completed and drip lines were placed. During the growing season, weeds, pests, and diseases were controlled periodically and all the experimental units received the normal cultural practices.

Seeds of bottle gourd landrace El-Arishy were sown in 84-cell styrophom trays under greenhouse conditions from the beginning of March. The trays were filled with soil mixture (Peat moss and vermiculite mixes in 1:1 $\mathrm{v} / \mathrm{v}$, enriched with different nutrients). After emerging, seeds were watered regularly with diluted fertilizer solution $(0.2 \mathrm{~g} / \mathrm{L}$ of $6: 6: 6, \mathrm{~N}: \mathrm{P}: \mathrm{K}$ composite fertilizer). At four true leaves stage, the seedlings were transplanted to the open field in the middle of April.

Two factors, plant density and nitrogen level were studied. Plant densities were $60 \mathrm{~cm}$ (3500 plant/faddan), $90 \mathrm{~cm} \quad(2350$ plant/faddan $)$ and $120 \mathrm{~cm} \quad(1750$ plant/faddan). For nitrogen fertilizer factor, two rates was applied, the first was $10 \mathrm{~g} \mathrm{~N} /$ plant which equal to $35,23.5$ and $17.5 \mathrm{~kg} \mathrm{~N}$ per faddan for tested plant densities, respectively. The second one was $20 \mathrm{~g}$ N/plant which equal to 70,47 and $35 \mathrm{~kg} \mathrm{~N}$ per faddan for tested plant densities, respectively. Ammonium nitrate $(33.5 \%)$ as nitrogen source was used and the application started after one month from transplanting.

\section{Experimental design}

The experiment involved three plant densities and two rates of nitrogen fertilizer. Consequently, the experiment comprised of six combinations of treatments, arranged in a complete randomized blocks, laid out in split plot design and each treatment was replicated three times. Each experimental unit contained 41, 27 and 20 plants for each plant density, respectively. The main plots represented the plant density, while the nitrogen fertilizer was devoted to the sub plot. The experimental unit represented by a single ridge of $25 \mathrm{~m}$ length and $2 \mathrm{~m}$ width. Drip irrigation system was used in this district.

\section{Recorded data \\ Plant growth and yield:}

Fresh and dry weights of the vegetative growth were determined after 4 months from transplanting. At maturity stage, four harvests were taken to calculate fruit yield characters such as average fruit weight (kg/fruit), average fruit length $(\mathrm{cm})$, average fruit number per faddan and average fruit yield per faddan.

\section{Mineral contents:}

Samples of shoots and fruits were taken at the end of the experiment (after 4 months from transplanting), oven dried at $70^{\circ} \mathrm{C}$ till constant weight. Dried samples were pulverized separately and samples of $0.5 \mathrm{gm}$ each were digested with a mixture of sulfuric acid and hydrogen peroxide. The percentage $(\%)$ of nitrogen was estimated using semi-micro-Kjeldahl method as described by Bremner (1996). The percentage (\%) of potassium was determined by flame photometer according to Page (1982). Also, phosphorus percentage (\%) was analyzed by a vanadate-molybdate method at $660 \mathrm{~nm}$ using spectrophotometer (Chapman and Pratt, 1982).

\section{Statistical analysis:}

Data were organized in split plot design in a completely randomized block (CRBD) and three replications, in which each replication was considered as a block. Experimental data were analyzed by analysis of variance (ANOVA) using CoStat. LSD test was used to compare the treatments means at $0.05 \%$ significance level of probability.

\section{RESULTS AND DISCUSSION}

\section{1- Foliage fresh and dry weight:}

Results presented in Table (1) regarding the main effects of plant density and nitrogen fertilizer level as well as their interaction on fresh and dry weight after four months from transplanting. The results show that the fresh and dry weights of bottle gourd were significantly decreased with increasing plant population (high plant density). This decrement was $15.25 \%$ and $19.33 \%$ for fresh weight and $21.09 \%$ and $12.50 \%$ for dry weight in the two seasons, respectively. The wider plant spacing gave the highest fresh and dry weight of bottle gourd in both seasons, this increment due to less competition for nutrients and other essential factors such as light and $\mathrm{CO}_{2}$. Our results are supported by the results of Babayee et al. (2012) who indicated that the dry weight of Cucurbita pepo was increased by increasing plant density.

Regarding the main effect of nitrogen fertilizer level, the results showed that fresh and dry weight were increased significantly with increasing nitrogen level from 10 to $20 \mathrm{~g} \mathrm{~N} /$ plant in both seasons. This increase was $20.73 \%$ and $15.05 \%$ for fresh weight and $42.9 \%$ and $7.25 \%$ for dry weight in the first and second seasons, respectively. It is well known that, nitrogen is one of the most important nutrients in crop production, because it affects photosynthetic efficiency and leaf development, which leads to dry matter production (Dordas and Sioulas, 2008). Also, nitrogen has a vital importance for plant growth due to being a part of amino acids, proteins, enzymes and chlorophyll molecules (Devlin and Witham, 1986). These results, regarding to a positive correlation between higher nitrogen level and higher fresh and dry weight are in accordance with the results of (Swaider et al., 1994; Olaniyi and Akanbi, 2007; Ng'etich et al., 2013 and Oloyede et al., 2013a, b) who reported that dry weight was increased with increasing nitrogen fertilization levels.

Concerning the interaction effects of plant population and nitrogen fertilizer, the presented data Table (1) proved that plants cultivated at low plant population (1750 plants/fad.) and fertilized with the higher nitrogen level ( $20 \mathrm{~g} \mathrm{~N} /$ fad.) produced bottle gourd plants with high fresh and dry weights and this effect was significant in both seasons. 


\section{2- Fruit yield characters:}

Main effects of plant population and nitrogen fertilizer and their interactions on average fruit weight (kg/fruit), average fruit length $(\mathrm{cm})$, total fruit number and total fruit yield (ton/fad.) are presented in Table (2) and 3. The presented data reveal that significant highest average fruit weight and average fruit length were associated with plants cultivated at low plant population.

However, fruit yield as well as fruit number per faddan were markedly increased by increasing number of plants per faddan (low plant density) in both seasons.

Table (1): Effect of plant population, nitrogen levels and their interactions on fresh and dry weight of El-Arishy bottle gourd landrace during the two seasons of 2012 and 2013.

\begin{tabular}{|c|c|c|c|c|c|}
\hline \multicolumn{2}{|c|}{ Treatments } & \multirow{2}{*}{\multicolumn{2}{|c|}{ Fresh weight (g) }} & \multirow{2}{*}{\multicolumn{2}{|c|}{ Dry weight (g) }} \\
\hline \multirow{2}{*}{$\begin{array}{l}\text { Plant } \\
\text { population/fad }\end{array}$} & \multirow{2}{*}{ N-rates (g/plant) } & & & & \\
\hline & & 2012 & 2013 & 2012 & 2013 \\
\hline 1750 & & $2658.50 \mathrm{a}$ & $3021.83 \mathrm{a}$ & $426.00 \mathrm{a}$ & $466.16 \mathrm{a}$ \\
\hline 2350 & & $2441.33 b$ & $2696.00 \mathrm{~b}$ & $360.16 \mathrm{~b}$ & $433.50 \mathrm{~b}$ \\
\hline \multirow[t]{3}{*}{3500} & & $2253.16 \mathrm{c}$ & $2437.66 \mathrm{c}$ & $336.16 \mathrm{c}$ & $407.91 \mathrm{c}$ \\
\hline & 10 & $2220.77 \mathrm{~b}$ & $2528.22 b$ & $308.00 \mathrm{~b}$ & $420.41 \mathrm{~b}$ \\
\hline & 20 & $2681.22 \mathrm{a}$ & $2908.77 \mathrm{a}$ & $440.22 \mathrm{a}$ & $451.30 \mathrm{a}$ \\
\hline \multirow{2}{*}{1750} & 10 & $2445.00 \mathrm{~b}$ & $2599.66 \mathrm{bc}$ & $374.66 \mathrm{~b}$ & $443.94 \mathrm{~b}$ \\
\hline & 20 & $2872.00 \mathrm{a}$ & $3444.00 \mathrm{a}$ & $477.33 \mathrm{a}$ & $488.39 \mathrm{a}$ \\
\hline \multirow{2}{*}{2350} & 10 & $2438.66 \mathrm{~b}$ & $2650.00 \mathrm{~b}$ & $299.33 \mathrm{c}$ & $411.05 \mathrm{c}$ \\
\hline & 20 & $2444.00 \mathrm{~b}$ & $2742.00 \mathrm{~b}$ & $421.00 \mathrm{ab}$ & $455.94 \mathrm{~b}$ \\
\hline \multirow{2}{*}{3500} & 10 & $1778.66 \mathrm{c}$ & $2335.00 \mathrm{c}$ & $246.33 \mathrm{c}$ & $406.23 \mathrm{c}$ \\
\hline & 20 & $2727.66 \mathrm{a}$ & $2540.33 \mathrm{bc}$ & $418.66 \mathrm{~b}$ & $409.59 \mathrm{c}$ \\
\hline
\end{tabular}

Values are the means of 3 plants per replicate (from 3 replicates). Values followed by the same letter within a column are not significantly different at the 0.05 level of probability according to LSD test.

The average fruit weight reduction associated with increasing plant population was compensated by the increasing in the number of fruits due to the increase in number of plants which resulted in overall increase in yield (Abd El Hamid and Elwan, 2011). These results are in conformity with those of Jan et al. (2000) on bottle gourd, Cushman et al. (2001) on pumpkin, Edelstein and Nerson (2001) on watermelon and Nerson (2002) on muskmelon, who reported that increasing plant population decreased the average fruit weight.

Fruit yield (number and ton/fad.) decreased in low plant population probably due to the environmental factors including light, space, water and soil which are not optimally used (Cormark and Smith, 1998; Rassam et al., 2007) and the decrease in number of fruit per area at low population could be attributed to reduction in number of plants per hectare and this consequently, reduce the number of fruitful branches (Knavel, 1988; Walters and Schultheis, 2000). These results are in a good line with those reported by Shukla and Prabhakar (1987) on bottle gourd, Maynard and Scott, 1998 on muskmelon, Jan et al. (2000) on bottle gourd, Kultur et al. (2001), Goreta et al. (2005), Ban et al. (2006), Ban et al. (2011) on watermelon, who reported that total yield and numbers of fruit per hectare were linearly increased with the increase in plant population.

Regarding to the main effect of nitrogen fertilizer, the results in Tables 2 and 3 illustrate that significantly the highest average fruit weight, average fruit length, total fruit yield and total fruit number per faddan were obtained in plants received higher nitrogen level $(20 \mathrm{~g}$ $\mathrm{N} /$ plant), in both seasons. The increment in nitrogen fertilization lead to vigorous growth which increased the net photosynthetic capacity of plants, and thus the plants produced more fruits per plant and per hectare (Kultur et al., 2001). The obtained results are in harmony with some studies which reported that increasing nitrogen application, increased fruit yield, fruit number per ha and average fruit weight (Jan et al. (2000) on bottle gourd; Ansary et al. (2004) and Harrelson et al. (2008) on pumpkin; Ahmed et al. (2007) and He-xi et al. (2011) on cucumber).

Interaction effect between plant population and nitrogen fertilizer on fruit characters are presented in Tables 2 and 3. Results show that (Table 2), in most cases, the highest values of average fruit weight and average fruit length were observed in fruits of bottle gourd plants cultivated at low plant population and fertilized with high nitrogen rate $(20 \mathrm{~g} \mathrm{~N} /$ plant $)$. However, the highest fruit yield and fruit number per faddan were noticed when higher plant population (3500 plants per faddan) interacted with high nitrogen rate (20g N/faddan).

\section{3- Plant mineral elements content:}

The effect of plant population and nitrogen rate and their interaction on the content of NPK percentage in shoots (leaves + stems) and fruits of Al-Arishy bottle 
gourd genotype in the two seasons are presented in Tables 4 and 5. The results of plant population show that nitrogen percentage in shoots and fruits significantly decreased with increasing number of plants per faddan in both seasons. However, the percentage of phosphorus and potassium contents were not significantly affected by plant population in both seasons (Tables 4 and 5). The percentage of nitrogen and phosphorus were increased significantly by increasing nitrogen level from $10 \mathrm{~g} \mathrm{~N} /$ plant to $20 \mathrm{~g}$ $\mathrm{N} /$ plant. However, shoots and fruits potassium content did not significantly change by increasing nitrogen rate in both seasons (Tables 4 and 5). The higher $\mathrm{N}$ content in nitrogen fertilized plants could be connected with the positive effect of nitrogen in some important physiological processes (Chaturved, 2005).

Table (2): Effect of plant population nitrogen levels and their interactions on average of fruit weight and fruit length of El-Arishy bottle gourd landrace, during the two seasons of 2012 and 2013.

\begin{tabular}{|c|c|c|c|c|c|}
\hline \multicolumn{2}{|c|}{ Treatments } & \multirow{2}{*}{\multicolumn{2}{|c|}{$\begin{array}{l}\text { Average fruit weight } \\
\text { (kg/fruit) }\end{array}$}} & \multirow{2}{*}{\multicolumn{2}{|c|}{$\begin{array}{l}\text { Average fruit } \\
\text { length }(\mathrm{cm})\end{array}$}} \\
\hline $\begin{array}{l}\text { Plant } \\
\text { population/fad }\end{array}$ & N-rates (g/plant) & & 2013 & & $\frac{\text { m) }}{2013}$ \\
\hline 1750 & & $0.79 \mathrm{a}$ & $0.62 \mathrm{a}$ & $28.55 \mathrm{a}$ & $26.33 \mathrm{a}$ \\
\hline 2350 & & $0.73 \mathrm{~b}$ & $0.52 \mathrm{~b}$ & $27.93 \mathrm{a}$ & $25.63 \mathrm{~b}$ \\
\hline \multirow[t]{3}{*}{3500} & & $0.60 \mathrm{c}$ & $0.46 \mathrm{c}$ & $26.15 \mathrm{~b}$ & $24.58 \mathrm{c}$ \\
\hline & 10 & $0.69 \mathrm{~b}$ & $0.50 \mathrm{~b}$ & $27.06 \mathrm{~b}$ & $25.22 \mathrm{~b}$ \\
\hline & 20 & $0.72 \mathrm{a}$ & $0.56 \mathrm{a}$ & $28.02 \mathrm{a}$ & $25.81 \mathrm{a}$ \\
\hline \multirow{2}{*}{1750} & 10 & $0.78 \mathrm{~b}$ & $0.57 \mathrm{~b}$ & $28.26 \mathrm{ab}$ & $26.06 \mathrm{~b}$ \\
\hline & 20 & $0.81 \mathrm{a}$ & $0.66 \mathrm{a}$ & $28.83 \mathrm{a}$ & $26.60 \mathrm{a}$ \\
\hline \multirow{2}{*}{2350} & 10 & $0.72 \mathrm{~d}$ & $0.50 \mathrm{c}$ & $27.80 \mathrm{ab}$ & $25.43 b c$ \\
\hline & 20 & $0.74 \mathrm{c}$ & $0.53 b c$ & $28.06 \mathrm{ab}$ & $25.83 \mathrm{~b}$ \\
\hline \multirow{2}{*}{3500} & 10 & $0.57 \mathrm{f}$ & $0.43 \mathrm{~d}$ & $25.13 \mathrm{c}$ & $24.16 \mathrm{~d}$ \\
\hline & 20 & $0.63 \mathrm{e}$ & $0.49 \mathrm{c}$ & $27.16 \mathrm{~b}$ & $25.00 \mathrm{c}$ \\
\hline
\end{tabular}

Values are the means of 3 plants per replicate (from 3 replicates). Values followed by the same letter within a column are not significantly different at the 0.05 level of probability according to LSD test.

Table (3): Effect of plant population, nitrogen levels and their interactions on fruit yield and numbers of El-Arishy bottle gourd landrace, during the two seasons of 2012 and 2013.

\begin{tabular}{|c|c|c|c|c|c|}
\hline \multicolumn{2}{|c|}{ Treatment } & \multirow{2}{*}{\multicolumn{2}{|c|}{$\begin{array}{c}\text { Total fruit } \\
\text { No./fad. }\end{array}$}} & \multirow{2}{*}{\multicolumn{2}{|c|}{$\begin{array}{l}\text { Total fruit yield } \\
\text { (Ton/fad.) }\end{array}$}} \\
\hline \multirow{2}{*}{$\begin{array}{l}\text { Plant } \\
\text { population/fad. }\end{array}$} & \multirow{2}{*}{$\begin{array}{l}\text { N-rates } \\
\text { (g/plant) }\end{array}$} & & & & \\
\hline & & 2012 & 2013 & 2012 & 2013 \\
\hline 1750 & & $6006 \mathrm{c}$ & $4277 \mathrm{c}$ & $4.79 \mathrm{c}$ & $2.69 \mathrm{c}$ \\
\hline 2350 & & $9534 \mathrm{~b}$ & $8736 \mathrm{~b}$ & $6.97 \mathrm{~b}$ & $4.56 \mathrm{~b}$ \\
\hline \multirow[t]{3}{*}{3500} & & $12768 \mathrm{a}$ & $12467 \mathrm{a}$ & $7.76 \mathrm{a}$ & $5.84 \mathrm{a}$ \\
\hline & 10 & 8596 b & $7401 b$ & $5.72 \mathrm{~b}$ & $3.54 \mathrm{~b}$ \\
\hline & 20 & $10276 \mathrm{a}$ & $9585 \mathrm{a}$ & $7.30 \mathrm{a}$ & $5.18 \mathrm{a}$ \\
\hline \multirow{2}{*}{1750} & 10 & $5124 \mathrm{f}$ & $2912 \mathrm{f}$ & $3.99 \mathrm{e}$ & $1.68 \mathrm{~d}$ \\
\hline & 20 & $6888 \mathrm{e}$ & 5642 e & $5.59 \mathrm{~d}$ & $3.71 \mathrm{c}$ \\
\hline \multirow{2}{*}{2350} & 10 & 8904 d & $7644 \mathrm{~d}$ & $6.42 \mathrm{c}$ & $3.88 \mathrm{c}$ \\
\hline & 20 & $10164 \mathrm{c}$ & $9828 \mathrm{c}$ & $7.53 \mathrm{~b}$ & $5.24 b$ \\
\hline \multirow{2}{*}{3500} & 10 & $11760 \mathrm{~b}$ & $11648 \mathrm{~b}$ & $6.75 \mathrm{c}$ & $5.06 \mathrm{~b}$ \\
\hline & 20 & $13776 \mathrm{a}$ & $13286 \mathrm{a}$ & $8.76 \mathrm{a}$ & $6.61 \mathrm{a}$ \\
\hline
\end{tabular}

Values are the means of 3 plants per replicate (from 3 replicates). Values followed by the same letter within a column are not significantly different at the 0.05 level of probability according to LSD test. 
These results are in conformity with Aroiee and Omidbaigi (2004) on pumpkin, Goreta et al. (2005) on watermelon, Olaniyi and Akanbi (2007) on pumpkin and Herdari and Mohammad (2012) on bitter melon who reported that mineral elements contents in the shoots and fruits increased as application of nitrogen increased.

Concerning the interaction effect of plant population and nitrogen fertilizer, the results show that there was no clear trend for nitrogen and phosphorus percentage, in bottle gourd shoots and fruits in both seasons. In addition the highest nitrogen and phosphorus values were found in shoots and fruits of plants obtained from low population (1750 plant per faddan) combined with high nitrogen level (Tables 4 and 5). The presented results showed generally that potassium content in shoots and fruits did not affect significantly by any interaction treatments in both seasons (Tables 4 and 5).

In conclusion, the results showed that the higher fruit yield (ton/fad.) and fruit number were found in the combination of high plant population (3500 plant/fad.) with high nitrogen rate $(20 \mathrm{~g} \mathrm{~N} /$ plant $)$.

Table (4): Effect of plant population, nitrogen levels and their interactions on foliage NPK percentage of El-Arishy bottle gourd landrace, during the two seasons of 2012 and 2013.

\begin{tabular}{llcccccc}
\hline & \multicolumn{2}{c}{ Treatment } & \multicolumn{2}{c}{ N\% } & \multicolumn{2}{c}{ P\% } & \multicolumn{2}{c}{ K\% } \\
\hline $\begin{array}{l}\text { Plant } \\
\text { population/fad. }\end{array}$ & $\begin{array}{l}\text { N-rates } \\
\text { (g/plant) }\end{array}$ & $\mathbf{2 0 1 2}$ & $\mathbf{2 0 1 3}$ & $\mathbf{2 0 1 2}$ & $\mathbf{2 0 1 3}$ & $\mathbf{2 0 1 2}$ & $\mathbf{2 0 1 3}$ \\
\hline $\mathbf{1 7 5 0}$ & & $2.02 \mathrm{a}$ & $2.11 \mathrm{a}$ & $0.28 \mathrm{a}$ & $0.28 \mathrm{a}$ & $3.08 \mathrm{a}$ & $2.22 \mathrm{a}$ \\
$\mathbf{2 3 5 0}$ & $1.83 \mathrm{~b}$ & $2.06 \mathrm{a}$ & $0.27 \mathrm{a}$ & $0.30 \mathrm{a}$ & $3.03 \mathrm{a}$ & $2.27 \mathrm{a}$ \\
$\mathbf{3 5 0 0}$ & & $1.76 \mathrm{~b}$ & $1.79 \mathrm{~b}$ & $0.24 \mathrm{a}$ & $0.25 \mathrm{a}$ & $3.28 \mathrm{a}$ & $2.63 \mathrm{a}$ \\
\hline & & $1.73 \mathrm{~b}$ & $1.81 \mathrm{~b}$ & $0.24 \mathrm{~b}$ & $0.24 \mathrm{~b}$ & $3.10 \mathrm{a}$ & $2.29 \mathrm{a}$ \\
& $\mathbf{1 0}$ & $2.01 \mathrm{a}$ & $2.16 \mathrm{a}$ & $0.29 \mathrm{a}$ & $0.31 \mathrm{a}$ & $3.16 \mathrm{a}$ & $2.45 \mathrm{a}$ \\
\hline $\mathbf{1 7 5 0}$ & $\mathbf{2 0}$ & $1.59 \mathrm{~b}$ & $2.00 \mathrm{bc}$ & $0.25 \mathrm{c}$ & $0.24 \mathrm{~b}$ & $3.03 \mathrm{a}$ & $2.22 \mathrm{a}$ \\
& $\mathbf{1 0}$ & $1.94 \mathrm{a}$ & $2.22 \mathrm{ab}$ & $0.30 \mathrm{ab}$ & $0.31 \mathrm{ab}$ & $3.14 \mathrm{a}$ & $2.22 \mathrm{a}$ \\
$\mathbf{2 3 5 0}$ & $\mathbf{2 0}$ & $2.07 \mathrm{a}$ & $1.87 \mathrm{c}$ & $0.23 \mathrm{c}$ & $0.26 \mathrm{ab}$ & $3.14 \mathrm{a}$ & $2.22 \mathrm{a}$ \\
& $\mathbf{1 0}$ & $1.60 \mathrm{~b}$ & $2.25 \mathrm{a}$ & $0.25 \mathrm{bc}$ & $0.35 \mathrm{a}$ & $2.92 \mathrm{a}$ & $2.33 \mathrm{a}$ \\
$\mathbf{3 5 0 0}$ & $\mathbf{2 0}$ & $2.00 \mathrm{a}$ & $1.58 \mathrm{~d}$ & $0.25 \mathrm{bc}$ & $0.23 \mathrm{~b}$ & $3.30 \mathrm{a}$ & $2.44 \mathrm{a}$ \\
& $\mathbf{1 0}$ & $2.04 \mathrm{a}$ & $2.00 \mathrm{bc}$ & $0.32 \mathrm{a}$ & $0.27 \mathrm{ab}$ & $3.25 \mathrm{a}$ & $2.82 \mathrm{a}$ \\
\hline
\end{tabular}

Values are the means of 3 plants per replicate (from 3 replicates). Values followed by the same letter within a column are not significantly different at the 0.05 level of probability according to LSD test.

Table (5): Effect of plant densities, nitrogen levels and their interaction on fruit NPK percentage of El- Arishy bottle gourd landrace, during the two seasons of 2012 and 2013.

\begin{tabular}{llclllll}
\hline & \multicolumn{2}{c}{ Treatment } & \multicolumn{2}{c}{$\mathbf{N \%}$} & \multicolumn{2}{c}{$\mathbf{P \%}$} & \multicolumn{2}{c}{ K\% } \\
\hline $\begin{array}{l}\text { Plant } \\
\text { population/fad. }\end{array}$ & $\begin{array}{l}\text { N-rates } \\
\text { (g/plant) }\end{array}$ & $\mathbf{2 0 1 2}$ & $\mathbf{2 0 1 3}$ & $\mathbf{2 0 1 2}$ & $\mathbf{2 0 1 3}$ & $\mathbf{2 0 1 2}$ & $\mathbf{2 0 1 3}$ \\
\hline $\mathbf{1 7 5 0}$ & & $1.76 \mathrm{a}$ & $1.60 \mathrm{a}$ & $0.33 \mathrm{a}$ & $0.30 \mathrm{a}$ & $2.98 \mathrm{a}$ & $3.22 \mathrm{a}$ \\
$\mathbf{2 3 5 0}$ & $1.57 \mathrm{~b}$ & $1.27 \mathrm{~b}$ & $0.36 \mathrm{a}$ & $0.30 \mathrm{a}$ & $3.16 \mathrm{a}$ & $3.08 \mathrm{a}$ \\
$\mathbf{3 5 0 0}$ & & $1.33 \mathrm{c}$ & $1.09 \mathrm{c}$ & $0.33 \mathrm{a}$ & $0.31 \mathrm{a}$ & $3.06 \mathrm{a}$ & $3.01 \mathrm{a}$ \\
\hline & $1.29 \mathrm{~b}$ & $1.19 \mathrm{~b}$ & $0.32 \mathrm{~b}$ & $0.29 \mathrm{~b}$ & $2.96 \mathrm{a}$ & $3.07 \mathrm{a}$ \\
& $\mathbf{1 0}$ & $1.82 \mathrm{a}$ & $1.44 \mathrm{a}$ & $0.36 \mathrm{a}$ & $0.31 \mathrm{a}$ & $3.18 \mathrm{a}$ & $3.14 \mathrm{a}$ \\
\hline \multirow{2}{*}{$\mathbf{1 7 5 0}$} & $\mathbf{2 0}$ & $1.52 \mathrm{ab}$ & $1.52 \mathrm{ab}$ & $0.32 \mathrm{~b}$ & $0.29 \mathrm{a}$ & $2.87 \mathrm{a}$ & $3.14 \mathrm{a}$ \\
& $\mathbf{1 0}$ & $2.04 \mathrm{a}$ & $1.68 \mathrm{a}$ & $0.34 \mathrm{~b}$ & $0.31 \mathrm{a}$ & $3.09 \mathrm{a}$ & $3.30 \mathrm{a}$ \\
$\mathbf{2 3 5 0}$ & $\mathbf{2 0}$ & $1.30 \mathrm{~b}$ & $1.17 \mathrm{c}$ & $0.33 \mathrm{~b}$ & $0.28 \mathrm{a}$ & $3.08 \mathrm{a}$ & $3.08 \mathrm{a}$ \\
& $\mathbf{1 0}$ & $1.68 \mathrm{ab}$ & $1.36 \mathrm{bc}$ & $0.39 \mathrm{a}$ & $0.31 \mathrm{a}$ & $3.25 \mathrm{a}$ & $3.08 \mathrm{a}$ \\
$\mathbf{3 5 0 0}$ & $\mathbf{2 0}$ & $1.17 \mathrm{~b}$ & $0.88 \mathrm{~d}$ & $0.33 \mathrm{~b}$ & $0.29 \mathrm{a}$ & $2.92 \mathrm{a}$ & $2.98 \mathrm{a}$ \\
& $\mathbf{1 0}$ & $1.61 \mathrm{ab}$ & $1.29 \mathrm{bc}$ & $0.34 \mathrm{~b}$ & $0.32 \mathrm{a}$ & $3.20 \mathrm{a}$ & $3.03 \mathrm{a}$ \\
\hline
\end{tabular}

Values are the means of 3 plants per replicate (from 3 replicates). Values followed by the same letter within a column are not significantly different at the 0.05 level of probability according to LSD test. 


\section{REFERENCES}

Abd El Hamid, K.E. and M.W.M. Elwan (2011). Dependence of pumpkin yield on plant density and variety. Am. J. Sci., 2: 636-643.

Ahmed, N., M.H. Baloch, A. Haleem, M. Ejaz and N. Ahmed (2007). Effect of different levels of nitrogen on the growth and production of cucumber. Life Sci. Int., J., 1: 99-102.

Ansary, S.H., P. Ganti and U. Thapa (2004). Effect of irrigation and nitrogen fertilization on yield and quality of pumpkin (Cucurbita moschata poir.). Vegetable. Sci., 31(1): 66-68.

Aroiee, H. and R. Omidbaigi (2004). Effects of nitrogen fertilizer on productivity of medicinal pumpkin. Proc. XXVI IHC. Future for Medicinal and Aromatic Plants Eds. L.E. Craker et al. Acta Hort., 629, ISHS Publication supported by Can. Int. Dev. Agency (CIDA).

Babayee, S.A., J. Daneshian, H. Baghdadi and M. Yousef (2012). Effect of plant density and irrigation interval on agronomical trait of Cucrbita pepo L. Tech. J. Engin. and App. Sci., 2(8): 258-261.

Baloch, Q.B., I. A. Kaleri, N. Memon, N. Sharif and Q.I. Chachar (2013). Effect of various sowing patterns on growth and yield of Indian squash (Citrullus vulgaris). J. Agric. Technol., 9(3): 625632.

Ban, D., S.G. Ban, M. Oplanic, J. Harrot, B. Novak and K. Zanic (2011). Growth and yield response of watermelon to in-row plant spacings and mycorrhiza. Chil. J. Agric. Res., 71(4): 497-502.

Ban, D., S. Goreta and J. Borosic (2006). Plant spacing and cultivar affect melon growth and yield components. Sci. Hortic., 109: 238-243.

Beevy, S.S. and P. Kuriachan (1996). Chromosome numbers of south Indian Cucurbitaceae and a note on the cytological evolution in the family. J. Cytol. Genet., 31:65-71.

Bremner, J.M. (1996). Total nitrogen. In: Methods of soil analysis, Part II, Sparks, D.L. (Ed.). SSSA Book Ser. 5. ASA and SSSA, Madison, WI, 1085-1121.

Chapman, H.D. and P.F. Pratt (1982). Method of analysis for soils, plants and water; Chapman Publisher: Riverside, California.

Chaturved, I. (2005). Effect of nitrogen fertilizers on growth, yield and quality of hybrid rice (Oryza sativa). Cent. Eur. Agric., 6(4): 611-618.

Cormark, H.T.H. and J.M. Smith (1998). Calendula officinalis, production potential and crop agronomy in southern England. Ind. Crops Prod., 7: 223-229.

Cushman, K.E., T.E. Horgan, D.H. Nagel, M. Maqbool and P.D. Gerard (2001). The effect of plant population on pumpkin yield. Annual Report of the North Mississippi Research \& Extension Center, Miss. Agric. \& For. Expt. Sta. Info. Bull., 375: 296-296.

Cushman, K.E., D.H. Nagel, T.E. Horgan and P.D. Gerard (2004). Plant population affects pumpkin yield components. Hort. Techno., 14(3): 326-331.
Cutler, H.C. and T.W. Whitaker (1967). Cucurbits of the Tehuacan Caves. In: Prehistory of the Tehuacan Valley (D.S. Byers, Hrsg.), Environment and Subsistence (Chapter 11), Vol. 1: 212-219, University of Texas Press, Austin/London.

Decker-Walters, D.S., M. Wilkins-Ellert, S. Chung and J.E. Staub (2004). Discovery and genetic assessment of wild bottle gourd [Lagenaria siceraria (Mol.) Standley; cucurbitaceae] from Zimbabwe. Economic Botany, 58(4): 501-508.

Devlin, M. R. and F. H. Witham (1986). Plant physiology, $4^{\text {th }}$ Ed. CBS Publisher and Distributor, Delhi. India, pp: 292-381.

Dordas, C.A. and C. Sioulas (2008). Safflower yield, chlorophyll content, photosynthesis, and water use efficiency response to nitrogen fertilization under rainfad conditions Ind. Crop Prod., 27: 7585.

Edelstein, M. and H. Nerson (2001). Genotype and plant density affect watermelon grown for seed consumption. Hort. Sci., 37(6): 981-983.

Erickson, D.L., B.D. Smith, A.C. Clarke, D.H. Sandweiss and N. Tuross (2005). An Asian origin for a 10, 000-year-old domesticated plant in the Americas. Proc. Natl. Acad. Sci., 102(18): 315320 .

Goreta, S., S. Perica, G. Dumičić, L. Bućan and K. Žanić (2005). Growth and yield of watermelon on polyethylene mulch with different spacings and nitrogen rates. Hort. Sci., 40: 366-369.

Haque, U., S.M. Ahmed, S. Hossain, M. Huda, A. Hossain, M.S. Alam, D. Mondal, W.A. Khan, M. Khalequzzaman and R. Haque (2009). Malaria prevalence in endemic districts of Bangladesh. PLoS ONE, 4(9).

Harrelson, E.R., G.D. Hoyt, J.L. Havlin and D.W. Monks (2008). Effect of planting date and nitrogen fertilization rates on no-till pumpkins. Hort. sci., 43(3): 857-861.

Heidari, M. and M.M. Mohammad (2012). Effect of rate and time of nitrogen application on fruit yield and accumulation of nutrient elements in Momordica charantia. J. of the Saudi Soc. Agric. Sci., 11: 129-133.

He-xi, Z., C. Dao-cai, W. Quan, F. Jun and F. Xiao-yu (2011). Yield and quality response of cucumber to irrigation and nitrogen fertilization under subsurface drip irrigation in solar greenhouse. Agric. Sci. China., 10(6): 921-930.

Holliday, R. (1960). Plant population and crop yield. Nature, 186(4718): 22-24.

Jan, N.D., M. Iqbal, A. Ghafoor, K. Waseem and M.S. Jillani (2000). Effect of NPK fertilizer and spacing on yield of Bottle Gourd (Lagenaria siceratia L). Pakistan J. Biol. Sci., 3(3): 448-449.

Knavel, D.E. (1988). Growth, development, and yield potential of short- internode muskmelon. J. Amer. Soc. Hort. Sci., 113: 595-599.

Kultur, F., H.C. Harrison and J.E. Staub (2001). Spacing and genotype affect fruit sugar concentration, yield and fruit size of muskmelon. Hort. Sci., 36 (2): 274-278. 
Latifi, M., A. Barimavandi, S. Sedaghathoor and S.R. Lipayi (2012). Sowing date and plant population effects on seed yield of Cucurbita pepo. Int. J. Agric. Biol., 14: 641-644.

Maynard, E.T. and W.D. Scott (1998). Plant spacing affects yield of 'Superstar' muskmelon. Hort Sci., 33: 52-54.

Morimoto, Y., P. Maundu, H. Fujimaki and H. Morishima (2005). Diversity of landraces of the white flowered gourd (Lagenaria siceraria) and its wild relatives in Kenya: fruit and seed morphology. Genet Resour Crop Evol., 52: 737747.

Morimoto Y and B. Mvere (2004) Lagenaria siceraria. In: Grubben GJH, Denton OA (eds) Vegetables. Plant resources of Tropical Africa 2. Backhuys Publishers/CTA, Wageningen/Leiden, pp. 353358.

Ndor, E. and N.S. Dauda (2013). Growth and yield performances of fluted pumpkins (Telferia occidentalis hook f.) Under organic and inorganic fertilizer on ultisols of north central Nigeria. Global J. Plant Ecophys., 3(1): 7-11.

Nerson, H. (2002). Relationship between plant density and fruit and seed production in muskmelon. J. Amer. Soc. Hort. Sci., 127(5): 885-859.

Ng'etich, O.K., A.N. Niyokuri, J.J. Rona, A. Fashaho and J.O. Ogweno (2013). Effect of different rates of nitrogen fertilizer on the growth and yield of zucchini (Cucurbita pepo cv. Diamant L.) Hybrid F1 in Rwandan high altitude zone. Int. J. Agric. and Crop Sci., 5(1): 54-62.

Olaniyi, J.O. and W.B. Akanbi (2007). Effect of organo mineral and inorganic fertilizers on the yield quality of fluted pumpkin (Telfaria occidentails hook.F.). Afric. crop Sci. Confer. Proc., 8: $347-$ 350.

Oloyede, F.M., G.O. Agbaje and I.O. Obisesan (2013a). Effect of NPK Fertilizer on Fruit Development of Pumpkin (Cucurbita pepo L.) 3(2): 403-411.

Oloyede, F.M., G.O. Agbajae and I.O. Obisean (2013b). Analysis of pumpkin (Cucurbita pepo L.) biomass yield and its components as affected by nitrogen, phosphorus and potassium (NPK) fertilizer rates. Afric. J. Agric. Res., 8(37): 46864692.
Page, A.L. (1982). Methods of soil analysis. $2^{\text {nd }}$ Ed. Part1, Soil Sci. Soc. Amer. Madison Wisc. USA.

Pant, M.M. (1979). Dependence of Plant Yield on Density and Planting Pattern. Annals of Botany, 44(4): 513-516.

Rassam, G., M. Naddaf and F. Sefidcon (2007). Effect of planting date and plant density on yield and seed yield components of anise (Pimpinella anisum L.). Pajouhesh Sazandegi., 75: 127-133.

Reiners, S. and D.I.M. Riggs (1997). Plant spacing and variety affect pumpkin yield and fruit size, but supplemental nitrogen does not. Hort Sci., 32(6): 1037-1039.

Sabo, M.U., M.A. Wailare, M. Aliyu, S. Jaris and Y.M. Shuaibu (2013). Effect of NPK fertilizer and spacing on growth and yield of watermelon (Citrillus lanatus L) in Katlungo local Government area of Gombe state, Scholarly. J. Agric. Sci., 3(8): 325-330.

Shukla, V. and B.S. Prabhakar (1987). Effect of plant spacing and fertilizer on the yield of bottle gourd. South Ind. J. Hort., 35: 453-454.

Swaider, J.M., S.K. Sipp and R.E. Brown (1994). Pumpkin growth, flowering and fruiting response to nitrogen and potassium sprinkler fertigation in sandy soil. J. Am. Soci. Hortic. Sci., 119: 414419.

Thornley, J.H.M. (1983). Crop yield and planting density. Annal. Bot., 52(2): 257-259.

Walters, S.A. and J.R. Schultheis (2000). Influence of stand deficiencies and replanting on "Athena" muskmelon yields. Hort. Technol., 10(2): 362366.

Whitaker, T.W. (1971). Endemism and pre-Columbian migration of the bottle gourd, Lagenaria siceraria (Mol.) Standl. In: Riley CL, JC Kelley, CW Pennington, RL Runds (Eds). Man across the sea. Univ. of Texas Press, Austin. pp: 78-218.

Willey, R.W. and S.B. Heath (1969). The quantitive relation-ships between plant population and crop Yield. Adv. Agro., 21: 281-321.

Yetisir, H. and N. Sari (2003). Effect of different rootstock on plant growth, yield and quality of watermelon. Aust. J. Exp. Agric., 43(10): 12691274. 
تأثير الكثافة النباتية ومعدل التسميد النتروجينى على النمو الخضري والمحصول ومحتوى النبات من العناصر المعدنية في اليقطين المين

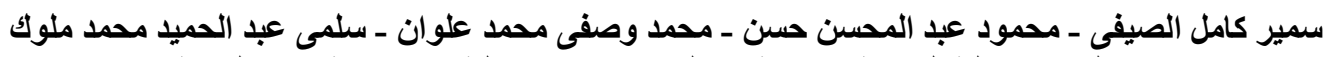

قسم البساتين - كلية الزراعة - جامعة قناة السويس - الاسماعيلية - جمهورية مصر العربية اعلية العبية

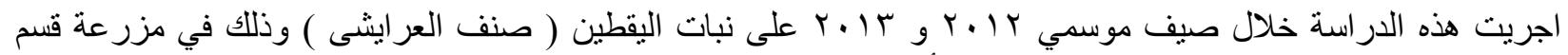

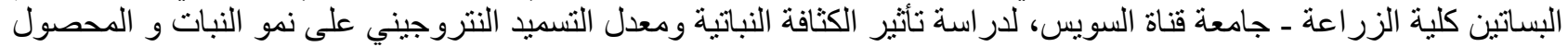

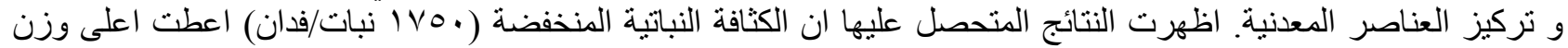

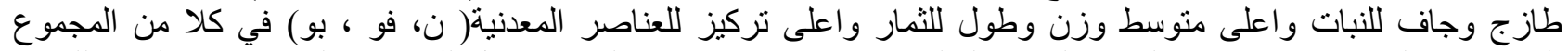

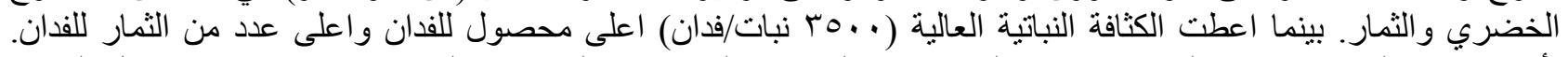

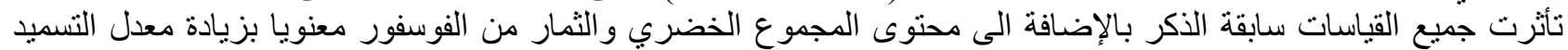

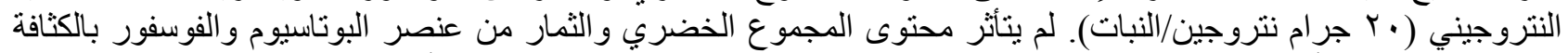

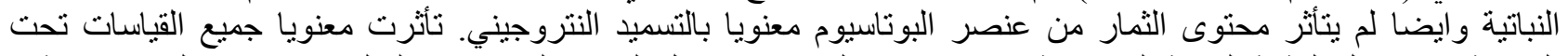

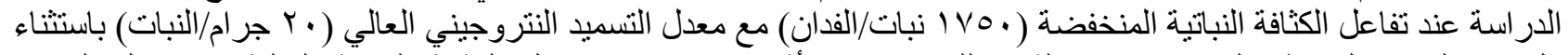

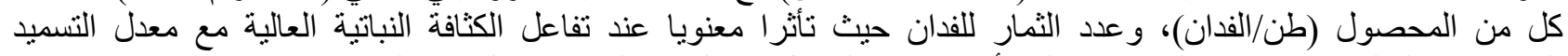
النتروجيني العالي، اما عنصر البوناسيوم فلم يتأثر معنويا بالتفاعل بين الكثافة النبانية النية مع التسميد النتروجيني. 